\title{
¿Hubo dengue autóctono en Chile?
}

\author{
ENRIQUE LAVAL R.
}

\section{¿Was there auchtochtonous Dengue in Chile?}

El dengue es una enfermedad producida por un virus ARN perteneciente a la familia de los Flaviviridae, del cual se han identificado cuatro serotipos, sin inmunidad cruzada entre ellos. Es transmitida de hombre a hombre por la picadura del mosquito Aedes aegypti, su vector principal, reconociéndose otros como el Aedes albopictus y el Aedes polynesienses. El virus es eliminado por la saliva de los vectores, los cuales se desarrollan principalmente en reservorios de aguas estancadas, en zonas o países tropicales y subtropicales, a nivel mundial ${ }^{4}$. El cuadro clínico fue descrito por primera vez en Filadelfia, en 1780, por Benjamín Rush, con el nombre de "bilious remitting fever", con motivo de una epidemia que se declaró en dicha ciudad. En 1956, se describió el cuadro llamado dengue hemorrágico, forma grave y de alta letalidad ${ }^{5}$.

El dengue se ha detectado en los siguientes países de América Latina: región del Caribe, Brasil, Colombia, Ecuador, México y Venezuela, donde se mantiene endémico con brotes epidémicos que comprometen a gran cantidad de gente ${ }^{4}$. Países vecinos a Chile, como Perú. Argentina y Bolivia, también presentan casos, pero en proporción menor. Los que se han diagnosticado en Chile, corresponderían a infecciones adquiridas fuera del país. Desde 1915, Chile se encuentra libre del vector Aedes aegvpti, siendo tarea obligatoria de nuestro país, vigilar la reinfestación.

En crónica de la Revista Médica de Chile de septiembre de 1889 , se lee "que sarampión y la roséola febril, continúan manifestándose todavía en lagunas poblaciones. Tenemos noticias que en dos o tres ciudades del Sur han vuelto a recrudecer. En esta larga epidemia, se ha observado algo muy singular, que no ha existido o ha pasado inadvertido en las anteriores: en el norte (provincia de Antofagasta, Tarapacá, Tacna y Arica), aparecía y se propagaba extensamente la entidad mórbida conocida hasta hoy con el nombre de fiebre Dengue. El doctor Luis Astaburaga, que se hallaba en Iquique, durante los meses de junio, julio y agosto, pudo reunir datos bastante completos sobre esta afección, que por ser muy rara en nuestras costas, pocos médicos la conocían, por motivo al principio hubo ciertas dudas y vacilaciones.

Había nacido este médico en Santiago el 16 de mayo de 1860, estudiando Medicina en la Universidad de Columbia de Nueva York, perfeccionándose en las Clínicas de Berlín y Viena. De regreso a Chile revalido su título el 4 de junio de 1888. En 1891 ejerció en Valparaíso.

Fue nombrado miembro del Consejo Superior de Higiene en 1907, falleciendo el $1^{\circ}$ de septiembre de 1914.

La comunicación del doctor Astaburuaga, intitulada "Epidemia de fiebre dengue en Iquique" fue presentada al Congreso Médico Chileno, reunido en Santiago del 15 al 22 de septiembre de 1889 y publicado en el Boletín Médico de marzo-abril de 1890: "consistía esta enfermedad en una fiebre infecciosa, caracterizada por una invasión repentina, con malestar general, dolores articulares y musculares muy pronunciados, cefalalgia, congestión de las conjuntivas, embarazo gástrico e hinchazón de los ganglios linfáticos. Al tercer día aparecería un sarpullido difuso y de color rojo que duraba corto tiempo y con su aparición bajaba un tanto la temperatura. A las pocas horas después recrudecía la fiebre y se desarrollaba un nuevo exantema que no siempre presentaba los mismos caracteres: ya simulaba el de la alfombrilla, ya el de la escarlatina, ora una simple urticaria, ora se producía las vesículas del pénfigo. La erupción terminal era acompañada de un descenso de la temperatura y seguida de descamación. En termino era generalmente favorables". Luego, Astaburaga habla de la nomenclatura de la enfermedad que "en los diferentes países en que ha aparecido la fiebre Dengue, se le ha aplicado distintos nombres; así por ejemplo, los ingleses la llaman "Dandy Fever" y "Pantomime Fever"; los norteamericanos "Breackbone fever" (fiebre rompe huesos) y "Broken-wing" (ala rota); los brasileros "Fiebre-polka" y los españoles "La Pantomima" y la "Piadosa". Se supone que la denominación dengue debe su origen a una corrupción española de la palabra inglesa dandy (petimetre), porque los agudos dolores que con ella se sufre hacen tomar a los pacientes una actitud extraña cuando anda.

Respecto a esto último, Pedro Pons también manifiesta que la palabra dengue "alude a la marcha especial, presuntuosa, dando, melindrosa denguera, con que el sujeto ser ve obligado a caminar debido a las mialgias lumbares que lo envaran.

Para el doctor Astaburuaga es "necesario dejar constancia que se han hecho esfuerzos para probar que el dengue tiene un origen parasitario y que se ha descrito un microbio, en la sangre de los enfermos bajo la forma de pequeños elementos esféricos fácil- 
mente coloreables por el azul de metileno en solución alcalina". A continuación dice "que a principio del año 1889 se produjo en Iquique una fiebre eruptiva que atacó indistintamente a niños adultos, siendo contados en el mes de julio los que habían escapado de contraer la enfermedad", sucediéndole a él, que a los 11 días después de examinar a un enfermo, pudo "observar y palpar en si mismo los síntomas de la enfermedad". Según el autor "nadie en Iquique ha confundido esta enfermedad con ninguna otra. Tan sólo el año pasado (1888), hubo en ese puerto una epidemia de alfombrilla y muchos de los que habrían contraído, se han visto ahora atacado por el dengue. Aunque esta enfermedad inocente, porque tiene un desenlace favorable, su presencia en Iquique demuestra que la salubridad de dicha ciudad deja mucho que desear".

En esa época algunos autores hacían notar que en varios países el dengue había precedido la aparición de epidemias de fiebre amarilla, por "lo que hay suficiente razón para temer que en el verano venidero se desarrolle en Iquique este terrible azote", concluye Astaburuaga. No sucedió así, sino que años después en 1912 hubo una epidemia de fiebre amarilla en Tocopilla, la que también llego a Iquique, porque en ambas ciudades existían las condiciones insalubres para la existencia del Aedes aegypti, transmisor de ambas enfermedades ${ }^{1}$.

\section{Bibliografía}

1.- Perret C. Diagnóstico de laboratorio del Dengue. Bol Soc Chil Infect; 1999: 7.

2.- Lasso M. El Dengue en las Américas. Bol Soc Chil Infect 1998; 4.

3.- Abarca K. Dengue. Bol Soc Chil Infect 1999; 6.

4.- Echevarria J. Llanos A. Infecciones tropicales en viajeros a Latinoamérica. Parte II. Rev Chil Infect 200: 17: $25-33$

5.- Astaburuaga $L$ Epidemia de fiebre dengue en Iquique. Bol Med 1890 Marzo-Abril: 53-4.

6.- Benavente D. Crónica. Rev Méd Chile 1899: 18: 5764.

7.- Laval M.E Noticias de los Médicos en Chile. Tomo 1 (A-B). Ed. Historia Medica Santiago de Chile 1970: 257.

8.- Pedro-Pons A. Tratado de Patología y Clínica Médica. Tomo IV. Enfermedades. Infecciosas, Intoxicaciones, Enfermedades Profesionales y Agentes Físicos. Salvat, Ed. Barcelona. España 1952. pp 460-3.

9.- Laval R E. Epidemia de fiebre amarilla en Tocopilla. 1912. Rev Chil Infect 1986; 2: 86-7.

10.- Urrutia R, Lanza L C. Catástrofes en Chile 15411992. Ed. La Noria. Santiago de Chile 1992; 235. 